\author{
ANNALS OF THE \\ UNIVERSITY OF CRAIOVA
}

Series: $\checkmark$ Biology

$\checkmark$ Horticulture

$\checkmark$ Food products processing technology

$\checkmark$ Environmental engineering

\author{
Vol. XXVI (LXII) - 2021
}

\title{
VARIATION OF SOME MORPHOLOGICAL CHARACTERISTICS OF Raphanus raphanistrum L. WEED FROM WHEAT CULTIVATED IN ECOLOGICAL- GREEN SYSTEM
}

\author{
Ionescu Nicolaie ${ }^{1 *}$, Popescu Diana Maria ${ }^{1}$, Badea Oana Daniela ${ }^{1}$, \\ Nicolaie Mariana Cristina ${ }^{1}$, Podea Maria Magdalena ${ }^{1}$, \\ Ghiorghe Cristina ${ }^{1}$, Gheorghe Marian Robert', Dinuță llie Cătălin ${ }^{1}$, \\ ${ }^{1 *}$ Agricultural Research and Development Station Pitești \\ Correspondence author. E-mail: nicolaeionescu50@gmail.com
}

Keywords: berries, MMSB, siliceous, Raphanus raphanistrum

\begin{abstract}
Lately, wild radish has been noted for its increased adaptability to various ecological conditions (Warwick \& Francis, 2005), thus being considered an invasive weed (CABI, 2016). Usually, the plant follows the winter wheat in the vegetation (Cheam \& Code, 1995; Cousens et al., 2001), although there has been an evolution of weeding in spring crops (Boström et al., 2003), such as sunflower. An explanation would also be due to the appearance of a certain degree of resistance to current herbicides (Brouillet et al., 2016). In organically grown wheat, the plant has undergone a new adaptation, less researched lately. Thus, the average height of the plants was $24 \mathrm{~cm}$. Such a plant had 5 branches each, weighed $1.35 \mathrm{~g}$ and formed 18 siliceous weighing $0.9 \mathrm{~g}$. The total number of siliceous grain segments on a plant was 64 , with a total biomass of $0.8 \mathrm{~g}$. The dimensions of the barrel-type silica segments were $4.7 \mathrm{~mm}$ long / $3.4 \mathrm{~mm}$ thick. The mass of one thousand grain segments (MTGS) was $13 \mathrm{~g}$. Simple correlations were established between all these characters. Significantly positive links were obtained between the morphological and biomass characteristics of the plant. Instead, negative correlations were found between the size of the fruit fragments and the other determinations of the plants. On the other hand, the mass of one thousand segments with grains was negatively correlated with the number of branches (.036), with the number of siliceous (-.160) and with the number of grains (-.205 *). The explanation consists in the fact that through the studied morphological characters, the weed demonstrated an increased adaptability in the culture of ecological wheat-green autumn wheat.
\end{abstract}

\section{INTRODUCTION}

Organic crops are experiencing a continuous development, due to the constant requirements to increase the protection of the agricultural environment. Observations have shown that weed species are also adapting to these new conditions (Holm et al., 1997; Darbyshire, 2003). This is also the case with this plant, considered the most widespread in the autumn wheat crop (Chèvre et al., Kartesz, 2011). Wild radish (Raphanus raphanistrum L., R. landra Schur., Raphanistrum segetum Baumg., wild radish, jointed charlock, jointed radish, jointed wild radish, sea radish, white charlock, RAPRA in Bayer code), has three subspecies: $R$. raphanistrum ssp. landra (Moretti ex. DC) Bonnier \& Layens, $R$ raphanistrum ssp. rostratus (DC) Thell., $R$. raphanistrum ssp sativus (L.) Domin. In the infested zone of the field are found the varieties: ochroleucus (Stockes) Peterm., with yellow petals, 
luteus L. with white petals and purpurascens Dumort., with petals in shades of pink. The plant is native to North Africa, Europe and parts of Asia (Holm et al., 1991). Currently, the plant is spreading on all continents (Warwick \& Francis, 2005). The number of chromosomes is $n=9$, respectively $2 n=18$ (Koelling \& Karoly, 2007). Among them are known six morphological types, marked between $A$ and $F$. Among them, type B represents the diploid form, and type $E$, the triploid one (Bett \& Lydate, 2003; USDA-ARS, 2016). The plant also has allelopathic characters (Norsworthy, 2003), and for some advantages: it is an important source of pollen and nectar, the flowers and leaves have a pungent taste - when used in food, and on the other hand the whole plant has some characters in biological control for aphids, such as Brevicoryne brassicae. When flowering, the plant is easily recognized in a chain by the color of the petals, either with shades of yellow (figure 1) or white (figure 2). The plant forms a relatively short stem with branches. The fruits are of the siliceous type, with several segments constricted between seeds (tapering) between them (figure 3.) The segments contain a single seed, round or oval in shape. $3 \mathrm{~cm}$ long The fruit fragment (bridge segment) has lengths of $4.0-5.5 \mathrm{~mm}$ and thickness (width) of 2.5$3.0 \mathrm{~mm}$ (figure 4). To define the ecotype of this weed, at maturity determinations were made for: plant height, number of branches on the stem, plant weight, number and weight of fruit, number and weight of fruit fragments, length and thickness of fruit fragments and mass of one thousand segments with grains (MTGS).

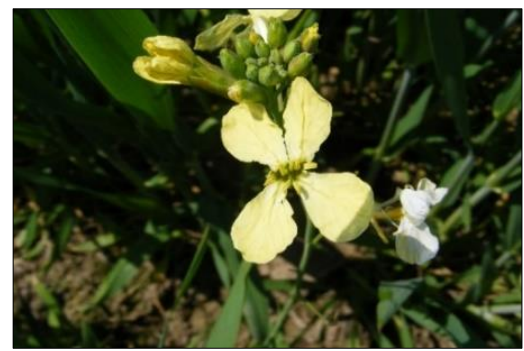

Figure 1. RAPRA ochroleucus (Stock.) P

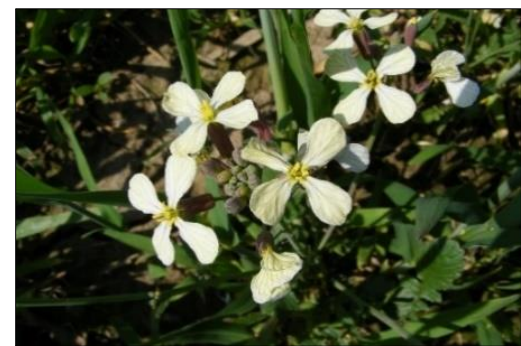

Pet. Figure 2. RAPRA luteus L.

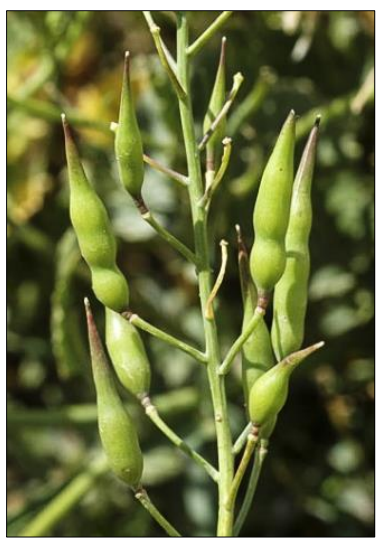

Figure 3. Siliqua of RAPRA

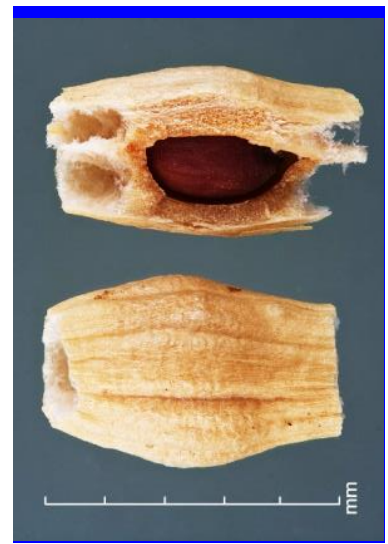

Figure 4. Fruit segment with grains 


\section{MATERIALS AND METHODS}

The determinations were made during June on the mature plants of Raphanus raphanistrum, in the last two years. Plants were chosen from the field with autumn wheat grown in an ecological system in the resort. Thus, 100 plants of $R$. raphanistrum were harvested, by cutting from the ground, from a soil of 5 ha area, by crossing in the zig-zag system. The plants were brought to the laboratory, they were kept for a period to reach the equilibrium humidity, after which each plant was analyzed separately. The measurements and determinations were as follows: plant height and weight, number of branches on a plant, number and weight of siliqua formed on a plant, number and weight of fruit segments on a plant, length and thickness of segment fragments, length tapering beak and the mass of a thousand grain segments (MTGS). The study of morphological characters in the species Raphanus raphanistrum was done in three directions: a) analyzes were made on the data sets obtained, by the method of frequency polygons (histograms). Class intervals were used in the method. The histograms present, on the one hand, the mod values (with the highest frequencies), then the limits of the variability intervals of the studied characters, as well as the specifics of each character of the plant ecotype in the analyzed area, b) simple correlations were established between the analyzed characters, with the help of which their tendencies within the studied ecotype could be observed. Excel was used to express values. The data obtained were compared with the theoretical values of transgression probabilities for $5 \%, 1 \%$ and $0.1 \%$, c) in the statistical calculation of all the determined characters, the analysis of variance (anova test) was used, namely on the variation strings. Statistical parameters were calculated using the formulas: $\overline{\mathrm{a}}=\Sigma x / \mathrm{n}$, where $\overline{\mathrm{a}}=$ average of the determinations, and $x=$ determined values, $S^{2}($ variance $)=1 /(n-1)\left[\sum x^{2}-\left(\sum x\right)^{2} / n\right], S($ standard error $)=\sqrt{ }\left(S^{2}\right)$, $S \%$ (coefficient of variation) $=\mathrm{S} / \overline{\mathrm{a}} .100$.

\section{RESULTS AND DISCUSSIONS}

Variability of plants and fruits. There is a competition between wheat and weed plants. In this interaction the weed forms plants with specific morphological characters. Thus, the height or waist was between 14 and $32 \mathrm{~cm}$ (figure 5). Of these, those with $24 \mathrm{~cm}(22 \%)$ dominated. Close to them were the plants that measured 22 $\mathrm{cm}(15 \%)$ and $26 \mathrm{~cm}(17 \%)$, respectively. The biomass of a plant was between 0.5 $\mathrm{g}$ and $5.5 \mathrm{~g}$. (Figure 6). Dominant were plants with weights of $1.5 \mathrm{~g}(34 \%)$, those with $2 \mathrm{~g}(26 \%)$ and those with $2.5 \mathrm{~g}(20 \%)$. Plants with $4 \mathrm{~g}$ and $4.5 \mathrm{~g}$ accounted for only $1 \%$ each.

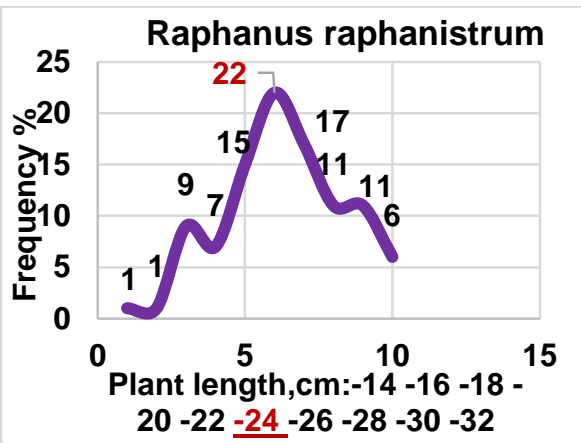

Figure 5. Frequencies of plant length

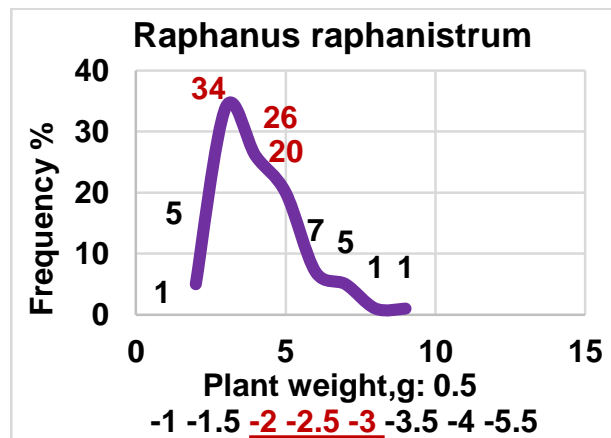

Figure 6. Frequencies of plant weight 
Through the competition with wheat, the growth and development of weeds between wheat plants, it also materialized through a branching of the stem. The number of branches was between 2 and 16 (figure 7). Plants with 4 branches dominated (39\%) and were followed by plants with 2 branches (17\%), those with 6 branches (19\%) and those with 8 branches (14\%). The fact that the weed branches in the wheat field is another important aspect of its adaptation in the crop plant (figure 8).

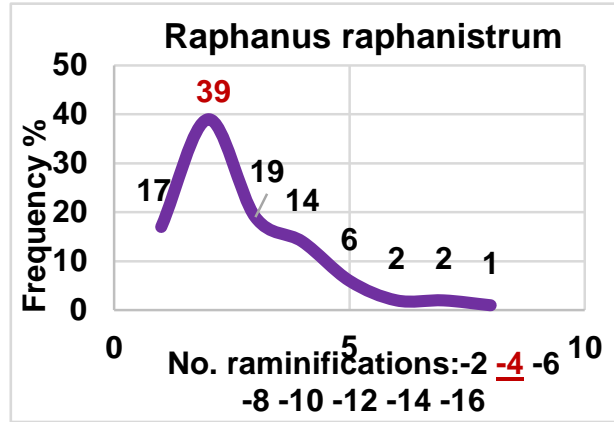

Figure 7. Frequencies of no. ramifications/stem

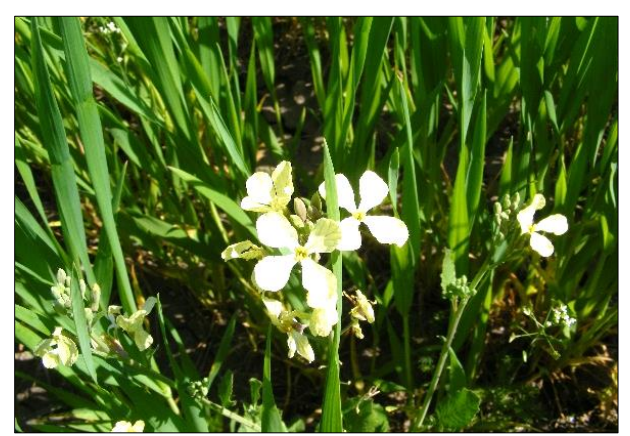

Figure 8. RAPRA from wheat

Specific siliquas were formed on the branches of the plants. Their number ranged from 5 to 50 per plant (Figure 9). They dominated the plants with 10-20 formed siliceous (26\%, 22\% and $23 \%$ respectively). Plants, both smaller and larger, accounted for only $1-2 \%$ of the total. The total mass of these fruits on a plant ranged from $0.5 \mathrm{~g}$ to $3.5 \mathrm{~g}$ (Figure 10). They dominated the siliceous ones that weighed $1 \mathrm{~g}(51 \%)$ and $1.5 \mathrm{~g}$ (21\%). Plants with 3-3.5 g accounted for only $1 \%$ of the total.

The segments of the total fruit were counted, after which they were weighed. Thus, the weed formed between 10 and 190 fruit segments (figure 11). Plants with 50 segments $(25 \%)$ and those with 70 segments $(28 \%)$ dominated. Plants with fewer segments (10) accounted for $1 \%$, and plants with 150-190 segments accounted for $6 \%$ in total. The biomass of these segments ranged between $0.5 \mathrm{~g}$ and $3.5 \mathrm{~g}$ (figure 12). Segments weighing $1.0 \mathrm{~g}(50 \%)$ dominated. This was followed by biomass of fruit segments of $0.5 \mathrm{~g} \mathrm{(22 \% )}$ and those with $1.5 \mathrm{~g}(19 \%)$. Plants of $R$. raphanistrum whose biomass of fruit segments was $2 \mathrm{~g}$ constituted $5 \%$ of the total, and the others with higher values constituted $1-2 \%$ of the total.

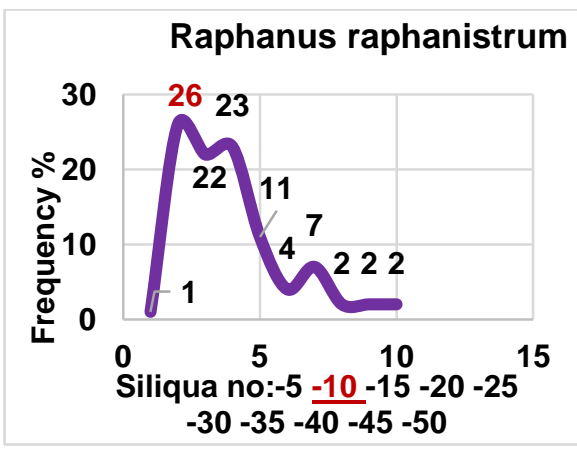

Figure 9. Frequencies of siliqua no./plant

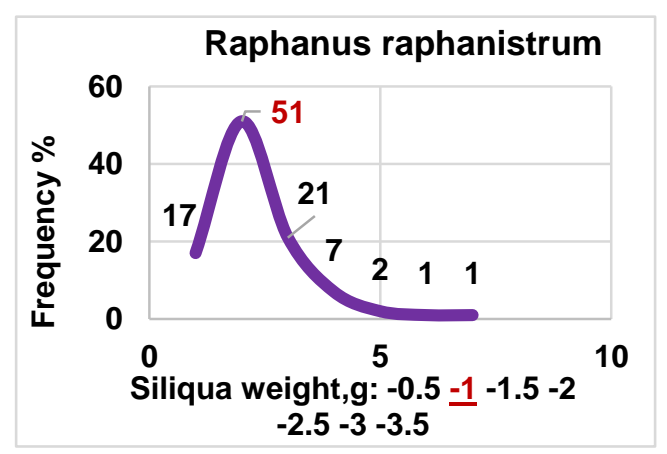

Figure 10. Frequency of siliqua weight 

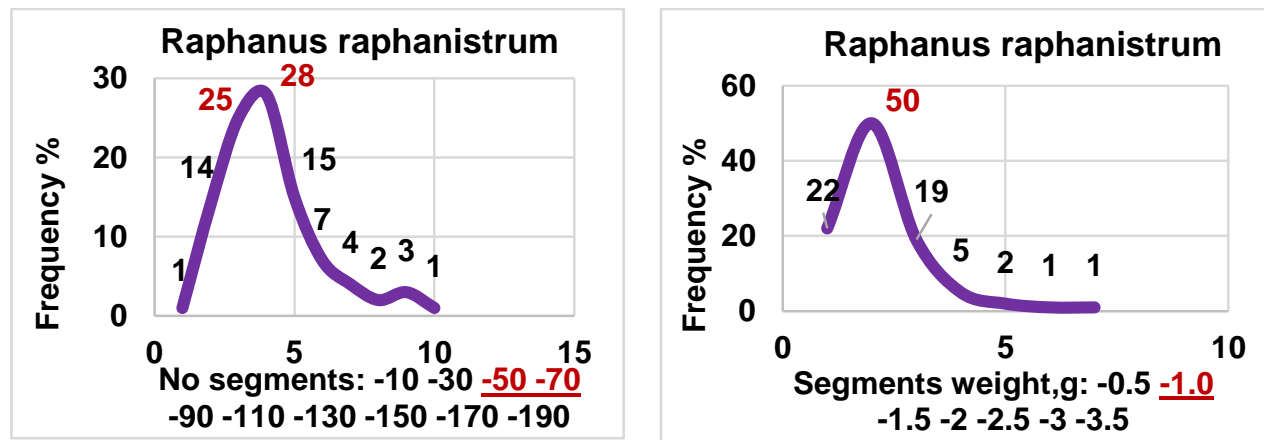

Figure 11. Frequencies of no. segments/plant Figure 12. Segments weight on a plant

The dimensions of the fruit segments refer to length and thickness. The ecotype of the analyzed burin had fruit lengths between 3 and $7 \mathrm{~mm}$ (figure 13). Of these, those with $4-5 \mathrm{~mm}$ in length $(43 \%$ and $34 \%$ respectively) dominated. The segments with $6 \mathrm{~mm}$ length (16\%) followed, and the fruits had smaller dimensions with $3 \mathrm{~mm} \mathrm{(5 \% )}$ and $7 \mathrm{~mm}(2 \%)$. The thickness of the segments measured in their middle portion, measured between $2.5 \mathrm{~mm}$ and $5.5 \mathrm{~mm}$ (figure 14). Of these, 3.5 $\mathrm{mm}$ thicknesses (46\%) dominated. Those with $3 \mathrm{~mm} \mathrm{(23 \% )}$ and those with $4.5 \mathrm{~mm}$ (19\%) followed. Thicker thicknesses of $2.5 \mathrm{~mm}$ constituted $4 \%$, and the largest, $7 \%$ $(5 \mathrm{~mm})$ and $1 \%(5.5 \mathrm{~mm})$.

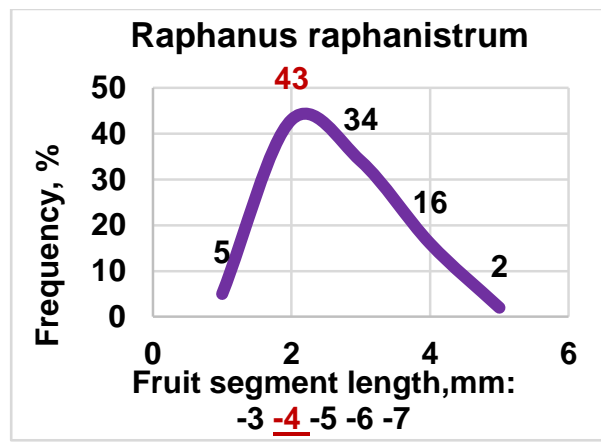

Figure 13. Frequencies of fruit segment length

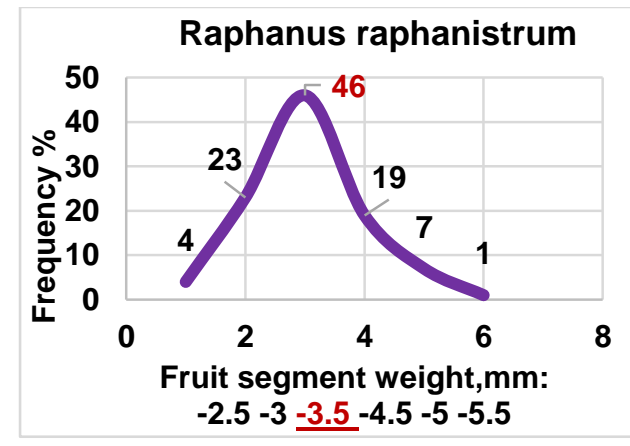

Figure 14. Frequencies of fruit segment weight

At the top of the siliqua is an elongated formation, in the form of a cone/beak, usually sharp. Measurements showed that its length was between 1 and $3 \mathrm{~cm}$ (figure 15). They dominated the beaks with $1.5-2 \mathrm{~cm}(44 \%$ and $37 \%$ respectively). $1 \mathrm{~cm}$ beak accounted for $11 \%$, and the longest in size were $2.5 \mathrm{~cm} \mathrm{(7 \% )} \mathrm{and} 3 \mathrm{~cm} \mathrm{(1 \% ).}$ The absolute weight of the siliqua segments (expressed by the mass of one thousand grain segments - MTGS), was between $8.5 \mathrm{~g}$ and $24.5 \mathrm{~g}$ (figure 16). They

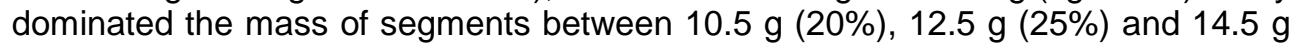
(20\%). Smaller MTGSs (8.5 g) accounted for 8\%, and heavier ones (20.5-22.5-24.5 g) accounted for $2-1 \%$. 

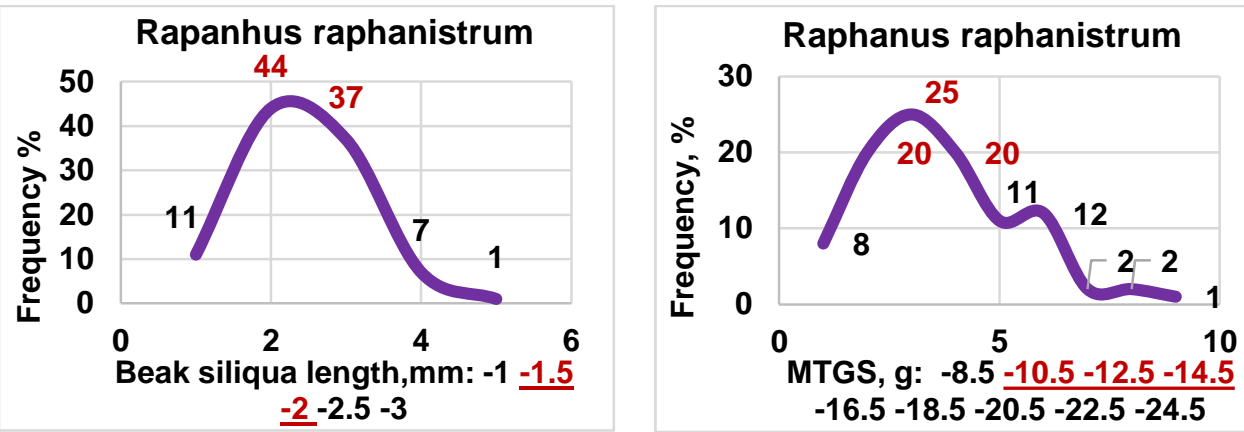

Figure 15. Frequencies of siliqua beak length Figure 16. The mass of a thousand grain segments

Correlations between main characters. The fruits showed quite different causal links between the observed characters - Table 1. Among them are the negative correlations between the size of the segments (length and thickness) with the other characters: plant lengths and different components of the fruit.

Table 1

Correlations between the main morphological characters of Raphanus raphanistrum

\begin{tabular}{|c|c|c|c|c|c|c|c|c|c|c|}
\hline Caracters & \begin{tabular}{|c|} 
NO. \\
ramific./ \\
plant \\
\end{tabular} & \begin{tabular}{|c|} 
Plant \\
weight, \\
$\mathrm{g}$ \\
\end{tabular} & $\begin{array}{c}\text { No. } \\
\text { Siliqua/ } \\
\text { plant } \\
\end{array}$ & $\begin{array}{c}\text { Siliqua } \\
\text { weight, } \\
\mathrm{g}\end{array}$ & $\begin{array}{c}\text { No. } \\
\text { segments } \\
\text { /plant }\end{array}$ & $\begin{array}{c}\text { Segm. } \\
\text { weight } \\
\mathrm{g}\end{array}$ & $\begin{array}{c}\text { Segm. } \\
\text { Length, } \\
\mathrm{mm}\end{array}$ & \begin{tabular}{|c} 
Segm. \\
width \\
$\mathrm{mm}$ \\
\end{tabular} & \begin{tabular}{|c} 
Beak \\
length, \\
$\mathrm{mm}$ \\
\end{tabular} & $\begin{array}{c}\text { MTGS, } \\
\mathrm{g}\end{array}$ \\
\hline Plant length & .361 & .356 & .203 & .204 & .153 & .185 & .316 & .152 & .064 & .053 \\
\hline $\begin{array}{l}\text { Ramificatio } \\
\text { n }\end{array}$ & 1 & .538 & .485 & .352 & .332 & .345 & .084 & .183 & -.009 & -.036 \\
\hline $\begin{array}{l}\text { Plant } \\
\text { weight }\end{array}$ & & 1 & .744 & .948 & .824 & .938 & .010 & .104 & .036 & .177 \\
\hline Siliqua no. & & & 1 & .761 & .828 & .747 & -.032 & -.032 & .014 & -.160 \\
\hline $\begin{array}{l}\text { Siliqua } \\
\text { weigh }\end{array}$ & & & & 1 & .883 & .995 & -.044 & .044 & .040 & .192 \\
\hline Fruit segm & & & & & 1 & .884 & -.106 & -.091 & .003 & -.205 \\
\hline $\begin{array}{l}\text { Segments } \\
\text { we }\end{array}$ & & & & & & 1 & -.041 & .044 & .014 & .204 \\
\hline $\begin{array}{l}\text { Segm. } \\
\text { length }\end{array}$ & & & & & & & 1 & .248 & .104 & .115 \\
\hline $\begin{array}{l}\text { Segm. } \\
\text { width }\end{array}$ & & & & & & & & 1 & .086 & 235 \\
\hline Beak length & & & & & & & & & 1 & .105 \\
\hline MTGS, g & & & & & & & & & & 1 \\
\hline
\end{tabular}

Similarly, the beak of the siliqua correlated, either insignificantly positively or negatively with all the other characters studied because the ecological condititions in which they grow and develop. Among the positive, important links were those between the dimensions of the siliqua segments (.248) and those between the MTGS with the mass of the siliqua (.192) and with the mass of the siliqua segments (.204). The higher the adaptability of $R$. raphanistrum plants in ecological- green grown wheat, the more developed they will be, with larger and heavier fruits. 
Statistical analysis of plant and fruit variability. Calculated for each analyzed character: mean $(\bar{a})$, variance $\left(\mathrm{s}^{2}\right)$, standard error of mean (s) and coefficient of variation $(\mathrm{CV}, \%)$. The statistical estimates performed revealed characteristic values of the $R$. raphanistrum ecotype from organic wheat culture. The values obtained were characteristic. The plant measured $24 \mathrm{~cm}$, formed 5 branches and weighed $1.35 \mathrm{~g}$. The plant formed 17.7 siliceous, which weighed $0.91 \mathrm{~g}$. The total number of segments in a fruit was 64 and weighed $0.80 \mathrm{~g}$. Segment length the fruit measured $4.67 \mathrm{~mm}$ and had a thickness of $3.37 \mathrm{~mm}$. The length of the beak at the top of the siliqua measured on average $1.49 \mathrm{~cm}$. The absolute mass of the formed segments was $12.9 \mathrm{~g}$ - table 2.

Table 2

Statistical indices of Raphanus raphanistrum species

\begin{tabular}{|l|c|c|c|c|c|c|c|c|c|c|c|}
\hline Indics & $\begin{array}{c}\text { Plant } \\
\text { length } \\
\text { cm }\end{array}$ & $\begin{array}{c}\text { No. } \\
\text { ramific } \\
\text { /plant }\end{array}$ & $\begin{array}{c}\text { Pltant } \\
\text { weight, } \\
\mathrm{g}\end{array}$ & $\begin{array}{c}\text { No. } \\
\text { siliqua/ } \\
\text { plant }\end{array}$ & $\begin{array}{c}\text { Siliqua } \\
\text { weight } \\
\mathrm{g}\end{array}$ & $\begin{array}{c}\text { No. } \\
\text { segmen. } \\
\text { /plant }\end{array}$ & $\begin{array}{c}\text { Segm. } \\
\text { weight, } \\
\mathrm{g}\end{array}$ & $\begin{array}{c}\text { Segm. } \\
\text { length } \\
\mathrm{mm}\end{array}$ & $\begin{array}{c}\text { Segm. } \\
\text { width. } \\
\mathrm{mm}\end{array}$ & $\begin{array}{c}\text { Beak } \\
\text { length, } \\
\mathrm{cm}\end{array}$ & $\begin{array}{c}\text { MTGS, } \\
\mathrm{g}\end{array}$ \\
\hline Mean & 24.2 & 5.07 & 1.35 & 17.7 & 0.91 & 64.0 & 0.80 & 4.67 & 3.37 & 1.49 & 12.9 \\
\hline $\mathrm{S}^{2}$ & 16.7 & 8.53 & 0.55 & 93.6 & 0.28 & 1251 & 0.22 & 0.76 & 0.23 & 0.16 & 11.8 \\
\hline $\mathrm{S}$ & 4.08 & 2.92 & 0.74 & 9.68 & 0.52 & 35.4 & 0.47 & 0.87 & 0.48 & 0.40 & 3.43 \\
\hline $\mathrm{VC} \%$ & 16.9 & 57.6 & 54.9 & 54.7 & 57.4 & 55.2 & 58.1 & 18.6 & 14.4 & 26.8 & 26.6 \\
\hline
\end{tabular}

\section{CONCLUSIONS}

a) A common species that causes significant damage is Raphanus raphanistrum $\mathrm{L}$. The weed is widespread in the south of the territory. The existing eco-type is very well adapted by special biology, both in conventional wheat crop and more recently in ecological- green wheat crop.

b) In order to control it through one's own management, it is good to know as many morphological characters as possible. From the observations it was found that a weed species, which expresses a wide variability of morphological characters, demonstrates higher degrees of adaptability, and complex control measures will be more extensive. Morphological variability, especially reproductive, being less known in ecological- green wheat, could express the existing eco-type in these conditions.

c) Average variability was found at the height of the plants (CV, 17\%) and at the dimensions of the silica segments (CV, 14-19\%). High variability was found for all other characters analyzed. The situation is due to the existence of a very high degree of competition between weed species and winter wheat plants grown in the ecological-green system.

\section{REFERENCES}

Bett K. E. \& Lydiate D. J. 2003. Genetic analysis and genome mapping in Raphanus. Genome 46: 423-430.

Boström, U., Milberg P. \& Fogelfors H. 2003. Yield loss inspring-sown cereals related to the weed flora in the spring. WeedSci. 51: 418-424.

Brouillet L., Coursol F., Favreau M. \& Anions M. 2016. VASCAN, the database vascular plants of Canada, http://data.canadensys.net/vascan/.

CABI. 2016. Invasive Species Compendium, www.cabi.org/isc.

Cheam A.H., Code G.R. 1995. The biology of Australian weeds. 24. Raphanus raphanistrum L. Plant Protection Quarterly, 10(1):2-13.

Chèvre A. M., Eber F., Darmency H., Fleury A., Picault H., Letanneur J. C. \& Renard M. 2000. Assessment of interspe-cific hybridization between transgenic 
oilseed rape and wild radish under normal agronomic conditions. Theoretical Applied Genetic, 100:1233-1239.

Cousens R. D., Warringa J. W., Cameron J. E. \& Hoy V. 2001. Early growth and development of wild radish (Raphanus raphanistrum L.) in relation to wheat. Australian Journal of Agriculture Researches, 52:755-769.

Darbyshire S. J. 2003. Inventory of Canadian agricultural weeds.Agriculture and Agri-Food Canada, Ottawa. Available: http://res2.agr.ca/ecorc/weeds_herb-es/titletitre_e.htm.

Holm L.G., Pancho J.V., Herberger J.P., Plucknett D.L. 1991. A geographic atlas of world weeds. Malabar, Florida, USA: Krieger Publishing Co. 1-391.

Holm L., Doll J., Holm E., Pancho J., Herberger J. 1997. World Weeds. Natural Histories and Distribution. New York, USA: John Wiley and Sons, Inc.

Kartesz J. T. 2011. The Biota of North America Program (BONAP). North American Plant Atlas. Chapel Hill, N.C., www.bonap.org/MapSwitchboard.html .

Koelling V. A., Karoly K. 2007. Self-pollen interference is absent in wild radish (Raphanus raphanistrum, Brassicaceae), a species with sporophytic selfincompatibility. American Journal of Botany, 94 (5): 896-900.

Norsworthy J. K. 2003. Allelopathic potential of wild radish (Raphanus raphanistrum). Weed Technology, 17: 307-313.

USDA-ARS 2016. Germplasm Resources Information Network-(GRIN), https://npgsweb.ars-grin.gov/gringlobal/taxon/taxonomysimple.aspx .

Warwick S. I., Francis A. 2005. The biology of Canadian weeds. 132. Raphanus raphanistrum. L. Canadian Journal of Plant Science. Eastern Cereal and Oilseed Research Centre. 85 (3): 709-733. 